\title{
Peningkatan Stabilitas Busa Dengan Nanofluida Silika Untuk Meningkatkan Produksi Gas Alam
}

\author{
(Enhancement Foam Stability With Silica Nanofluid To Improve Natural Gas Production)
}

\author{
Hendrix Abdul Ajiz ${ }^{1}$, Lizda Johar Mawarani ${ }^{1,2}$, Widiyastuti ${ }^{1}$, Heru Setyawan $^{1}$ \\ ${ }^{1}$ Departemen Teknik Kimia, Fakultas Teknologi Industri dan Rekayasa Sistem, \\ Institut Teknologi Sepuluh Nopember \\ ${ }^{2}$ Departemen Teknik Fisika, Fakultas Teknologi Industri dan Rekayasa Sistem, \\ Institut Teknologi Sepuluh Nopember \\ Jln. Teknik Kimia, Sukolilo, Surabaya 60111 \\ E-mail:sheru@chem-eng.its.ac.id
}

\begin{abstract}
Abstrak
Pemanfaatan gas alam sebagai sumber energi alternatif masih belum optimal karena masalah beban cairan pada sumur gas, surfaktan merupakan solusi yang menjanjikan untuk mengatasi masalah tersebut, namun dengan kondisi sumur gas yang ekstrem diperlukan stabilizer untuk meningkatkan stabilitasnya. Penelitian ini mempelajari pengaruh pencampuran surfaktan dan stabilizer berupa silika $\left(\mathrm{SiO}_{2}\right)$ nanopartikel yang disintesa dari sodium silikat $\left(\mathrm{Na}_{2} \mathrm{SiO}_{3}\right)$ untuk mendapatkan kondisi optimum nanofluida $\mathrm{SiO}_{2}$ terhadap waktu paruh busa yang menunjukkan kestabilannya. Silika nanopartikel disintesa dengan metode sol-gel dan dipertahankan dalam fase koloid stabil yang kemudian didispersikan ke dalam larutan surfaktan tanpa perlu penambahan bahan penyambung. Nanofluida $\mathrm{SiO}_{2}$ kemudian dimatangkan dengan variasi waktu dan konsentrasi silika. Dari hasil yang diperoleh menunjukkan bahwa peningkatan waktu pematangan dan konsentrasi silika memengaruhi nilai tegangan permukaan yang berakibat menurunkan waktu paruh busa. Penurunan kestabilan busa terjadi karena peristiwa adsorbsi fisik molekul surfaktan oleh silika nanopartikel yang ditunjukkan oleh nilai tegangan permukaan, karena silika yang bersifat hidrofilik akan membentuk ikatan fisik dengan surfaktan, semakin meningkatnya waktu pematangan dan konsentrasi silika yang didispersikan kedalam larutan akan meningkatkan adsorbsi molekul surfaktan pada permukaan silika dan menyebabkan terjadinya peningkatan nilai tegangan permukaan nanofluida. Stabilitas busa terbaik diperoleh pada sampel dengan waktu pematangan selama 6 jam dan konsentrasi silika 0,001\% menghasilkan waktu paruh selama 1170 menit yang jika dibandingkan dengan surfaktan tanpa penambahan silika nanopartikel hanya memeroleh waktu paruh selama 90 menit, sehingga penggunaan silika nanopartikel sebagai stabilizer memberikan efek yang signifikan terhadap kestabilan busa.
\end{abstract}

Kata Kunci: adsorbsi, kestabilan busa, nanofluida silika, surfaktan, tegangan permukaan.

\begin{abstract}
Utilization of natural gas as an alternative energy source is still not optimal due to the problem of liquid loading in gas wells, the surfactant is a promising solution to overcome this problem, but the extreme conditions of gas wells need stabilizers to increase their stability. This research studies the effect of mixing surfactants and stabilizers in the form of silica $\left(\mathrm{SiO}_{2}\right)$ nanoparticles derived from sodium silicate $\left(\mathrm{Na}_{2} \mathrm{SiO}_{3}\right)$ to obtain the optimum conditions of $\mathrm{SiO}_{2}$ nanofluid on foam half-time which shows its stability. Silica nanoparticles are synthesized by the sol-gel method and maintained in a stable colloidal phase and dispersed into a surfactant solution without the coupling agent. The SiO ${ }_{2}$ nanofluid then matured with variations in aging time and silica concentration. The results obtained indicate that the increase in aging time and silica concentration affect the surface tension value which results in a decrease in the half-time of the foam. The decrease in foam stability occurs due to the physical adsorption events of surfactant molecules by silica nanoparticles which are indicated by surface tension values, because hydrophilic silica will form physical bonds with surfactants, increasing the aging time and concentration of silica dispersed into the solution will increase the adsorption of surfactant molecules on the surface of silica and causes an increase in the surface tension value of nanofluids. The best foam stability was obtained in samples with an aging time of 6 hours and silica concentration of $0.001 \%$ which shows a half-time of 1170 minutes which when compared to surfactants without the addition of silica nanoparticles only has a half-time of 90 minutes, so the use of silica nanoparticles as stabilizer has a significant effect on foam stability.
\end{abstract}

Keywords: adsorption, foam stability, silica nanofluid, surfactant, surface tension.

\section{PENDAHULUAN}

Gas alam memiliki peranan yang sangat penting bagi keberlangsungan pemenuhan kebutuhan energi saat ini. Masalah yang sering dialami oleh sumur gas adalah beban cairan, yakni terkumpulnya air di dasar sumur sehingga berakibat menurunnya produksi gas hingga berhenti sama sekali [1]. Salah satu solusi yang menjanjikan untuk mengatasi masalah tersebut adalah dengan menggunakan surfaktan. surfaktan memiliki kemampuan untuk menurunkan tegangan permukaan cairan pada sumur gas, sehingga gas dapat mendorong cairan dari dasar sumur ke permukaan [2]. 
Kestabilan busa merupakan hal penting dalam karakteristik suatu surfaktan. Surfaktan yang dibutuhkan dalam mengatasi beban cairan di sumur gas adalah surfaktan yang dapat menghasilkan busa yang stabil. Untuk meningkatkan kestabilan busa, maka ada tiga hal utama yang harus diperhatikan adalah drainase, coarsening, coalescene. Drainase merupakan proses pemisahan fase liquid dan gas akibat adanya gaya gravitasi yang menjadikan lapisan film tipis pada busa menjadi kering dan tidak stabil, terjadinya peristiwa drainase dapat diamati seiring dengan lamanya waktu pengamatan. Terjadinya drainase juga dapat diikuti oleh perstiwa coarsening dan coalescene yang menyebabkan peningkatan ukuran busa menjadi lebih besar, akibatnya busa akan cenderung lebih mudah pecah dan tidak stabil dalam jangka waktu yang singkat [3].

Beberapa peneliti [4][5] menggunakan surfaktan amfoterik Gemini, memodifikasi struktur kimianya, dan menambahkan silika nanopartikel untuk meningkatkan stabilitas busanya. Silika nanopartikel yang ditambahkan disintesis dengan metode Stober menggunakan Tetra Etil Ortho Silicate (TEOS) sebagai sumber silika. Sintesis silika nanopartikel dari TEOS cenderung lebih mudah, karena pembentukan partikelnya yang relatif lambat sehingga mudah dikendalikan dan ukuran yang diinginkan lebih mudah didapatkan. Digunakan juga bahan penyambung dalam pencampuran surfaktan dan silika nanopartikel untuk membentuk ikatan antara silika dan surfaktan, pada prosesnya diperlukan waktu sintesa yang lebih lama hingga 12 jam agar diperoleh dispersi silika nanopartikel yang baik. Silika nanopartikel dapat membentuk lapisan film padat yang teradsorbsi pada antarmuka gas/liquid serta dapat meminimalisir terjadinya penuaan busa akibat perbedaan viskositas, sehingga busa menjadi lebih stabil dengan peningkatan waktu paruh pada kondisi optimumnya, namun kestabilan busa cenderung menurun seiring meningkatnya konsentrasi silika nanopartikel [9].

Pengembangan sintesis silika nanopartikel dari sodium silikat $\left(\mathrm{Na}_{2} \mathrm{SiO}_{3}\right)$ [6] telah dilakukan di departemen Teknik Kimia ITS. Karena itu dalam penelitian ini digunakan $\mathrm{Na}_{2} \mathrm{SiO}_{3}$ sebagai pengganti TEOS untuk mengurangi tahapan dalam sintesis silika nanopartikel, karena $\mathrm{Na}_{2} \mathrm{SiO}_{3}$ telah memiliki gugus silanol (Si-OH) yang diharapkan dapat membentuk ikatan dengan surfaktan walaupun tanpa penambahan bahan penyambung. Penggunaan silika nanopartikel yang disintesis dari $\mathrm{Na}_{2} \mathrm{SiO}_{3}$ lebih ekonomis dan proses sintesisnya juga lebih mudah dan efisien. Silika nanopartikel dihasilkan dalam fase koloid memiliki alasan untuk mengefisienkan waktu dalam proses sintesa dan waktu dispersinya, karena silika dalam fase koloid yang stabil memiliki muatan yang dapat terdispersi dengan baik tanpa perlakuan khusus seperti sonikasi yang lama seperti proses sintesa silika nanopartikel dari TEOS. Penambahan silika nanopartikel bertujuan untuk meningkatkan umur busa dengan membentuk dinding pembatas yang melapisi busa untuk mencegah terjadinya drainase akibat berbedaan kepadatan antara lapisan film liquid busa dengan lapisan film padat dari silika nanopartikel [7].

\section{METODE PENELITIAN}

\section{Bahan}

Bahan dasar yang digunakan dalam penelitian ini adalah sodium silikat dengan kadar $\mathrm{SiO}_{2}$ sebesar $28 \%, \mathrm{SiO}_{2}: \mathrm{Na}_{2} \mathrm{O}$ $=3,3$ (PT. PQ Silicas Indonesia), air demineralisasi (PT.Brataco), kalium hidroksida $(\mathrm{KOH})$ p.a Merck, asam klorida 37\% ( $\mathrm{HCl})$ (Mallinckrodt), resin flotrol-007,N,N Dimethyldodecylamine N-oxide Solution (SIGMA Life Science).

\section{Metode}

Sintesis silika nanopartikel diawali proses penukaran kation sodium silikat menggunakan resin sehingga diperoleh asam silisik aktif dengan $\mathrm{pH}$ 2. Setelah dipisahkan dari resin, ditambahkan larutan $\mathrm{KOH} 0,1 \mathrm{M}$ hingga diperoleh $\mathrm{pH} 8$, sol silika hasil sintesa dilakukan pengujian menggunakan zeta potensial dan analisa ukuran partikel (Malvern zetasier) untuk mengetahui kestabilan silika nanopartikel dalam fase liquid dan mengetahui ukuran partikel silika. Sol silika yang stabil kemudian didispersikan ke dalam larutan surfaktan dan diamati karakteristiknya pada waktu pematangan 0, 3, 6, 12, dan 24 jam. Adapun variasi konsentrasi silika yang ditambahkan adalah 0;0,001; 0,003; dan 0,005 (\%b/b). Karakteristik nanofluida surfaktan-silika yang diuji adalah tegangan permukaan dan kestabilan busa melalui waktu paruh busa. Tegangan permukaan diukur dengan metode kapiler dan pengukuran waktu paruh dilakukan dengan menggunakan gelas ukur $1000 \mathrm{~mL}$

\section{HASIL DAN PEMBAHASAN}

Sol silika hasil sintesis memiliki nilai zeta potensial sebesar -34,2 mV. Hal ini menunjukkan bahwa sol silika nanopartikel memiliki kestabilan yang baik dalam fase liquid, karena memiliki nilai zeta potensial lebih dari atau sama dengan absolut 30 [6]. Sol silika yang stabil dapat meminimalisir terjadinya aglomerasi, sehingga ukuran partikel silika dapat dipertahankan pada ukuran yang diharapkan.

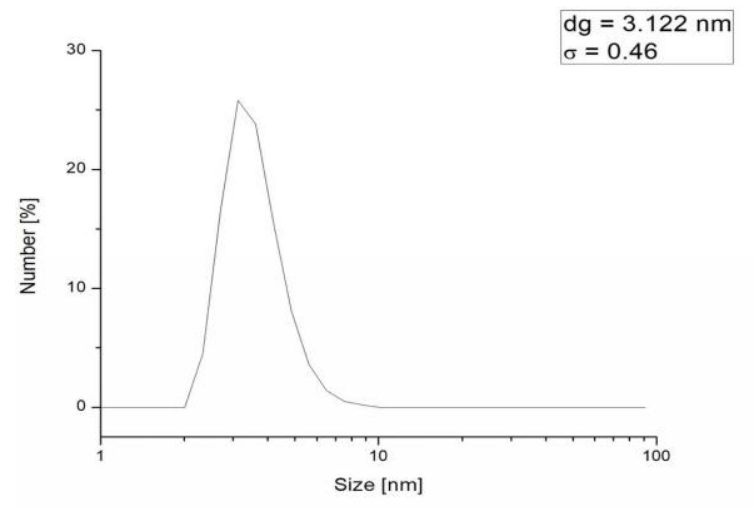

Gambar 1. Distribusi ukuran partikel

Gambar 1 menunjukkan distribusi ukuran partikel (PSA) diperoleh puncak intensitas tertinggi terdapat pada 3,122 nm, ukuran yang cukup kecil ini diharapkan dapat membentuk lapisan film padat yang seragam agar dapat meminimalisir terjadinya drainase pada busa, dan dapat menghasilkan busa yang stabil [4]. 


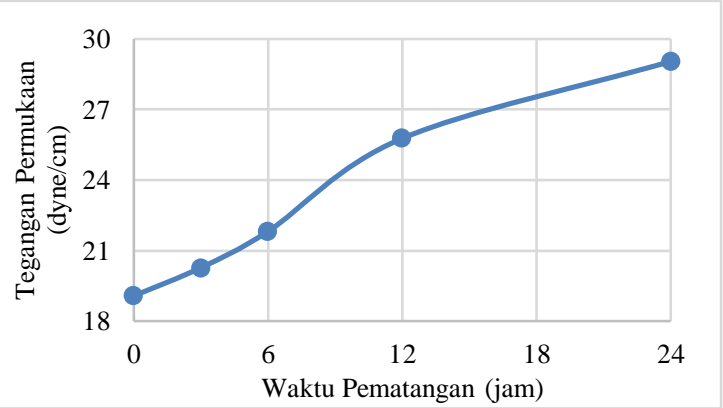

Gambar 2. Pengaruh waktu pematangan terhadap tegangan permukaan

Pencampuran surfaktan dengan silika nanopartikel dilakukan tanpa bahan penyambung. Pengamatan secara fisik hingga 24 jam terhadap nanofluida surfaktan-silika tidak terjadi endapan maupun perubahan warna yang menunjukkan tidak terbentuknya aglomerasi pada proses pematangan meskipun tanpa melalui proses sonikasi, sehingga dispersi silika nanopartikel dalam larutan surfaktan memiliki kestabilan yang baik.

Pengaruh waktu pematangan terhadap tegangan permukaan dilakukan pada penambahan silika nanopartikel dengan konsentrasi $0,003 \%$ mengacu pada penelitian sebelumnya [8], penelitian tersebut dilakukan tanpa waktu pematangan dan memelajari pengaruh penambahan silika nanopartikel dari $0 \%$ hingga $0,005 \%$ terhadap kestabilan busa. Hasilnya menunjukkan bahwa penambahan silika nanopartikel 0,003\% menyebabkan busa paling stabil, yakni mengalami penurunan busa hanya $5,74 \%$ setelah 24 jam, sedangkan sampel tanpa penambahan silika nanopartikel mengalami penurunan busa sebesar 9,98\% setelah 24 jam. Gambar 2 menunjukkan pengaruh waktu pematangan terhadap nilai tegangan permukaan, semakin lama waktu pematangan semakin tinggi tegangan permukaannya dengan peningkatan linier. Hal ini menjelaskan terjadinya peristiwa adsorbsi fisik molekul surfaktan oleh silika nanopartikel. Surfaktan memiliki dua sisi aktif yang dapat berikatan dengan senyawa yang bersifat polar pada satu sisi dan non polar pada sisi lainnya, karena sifatnya yang unik surfaktan dapat menurukan tegangan permukaan pada dua senyawa yang memiliki sifat kepolaran berbeda seperti air dan minyak. Meningkatnya nilai tegangan permukaan dapat terjadi karena berkurangnya sejumlah molekul surfaktan pada permukaan gas/liquid, sehingga semakin lama waktu pematangan yang dibutuhkan maka akan semakin banyak molekul surfaktan yang teradsorbsi pada permukaan silika [9][10]. Molekul surfaktan yang semula berada di permukaan liquid yang dengan itu tegangan permukaan cukup rendah, namun seiring dengan waktu akan teradsorbsi pada permukaan silika, menyebabkan molekul surfaktan di permukaan menjadi berkurang dan berakibat meningkatnya nilai tegangan permukaan.

Adapun pengaruh waktu pematangan terhadap waktu paruh busa menunjukkan kecenderungan yang berbeda dengan nilai tegangan permukaan. Gambar 3 menunjukkan bahwa sampai waktu pematangan 6 jam waktu paruh busa meningkat dan kemudian cenderung menurun pada waktu pematangan di atasnya. Dengan demikian waktu pematangan paling optimal adalah 6 jam.

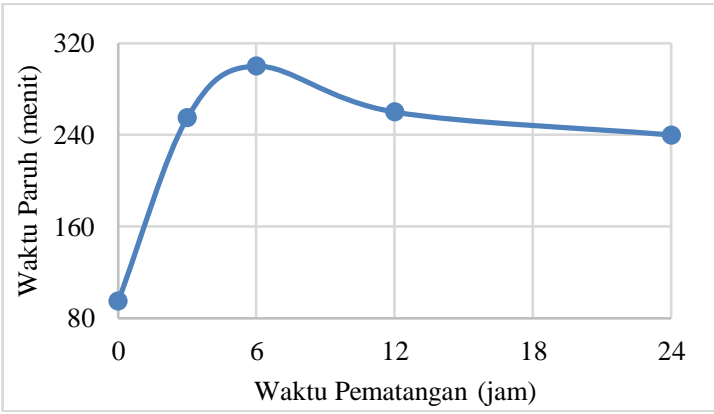

Gambar 3. Pengaruh waktu pematangan terhadap waktu paruh busa

Dengan waktu pematangan selama 6 jam kemudian dilakukan variasi konsentrasi silika0; 0,001; 0,003; dan $0,005(\% \mathrm{~b} / \mathrm{b})$. Dari hasil pengujian tegangan permukaan dan waktu paruh busa ditunjukkan oleh Gambar 4 dan Gambar 5.

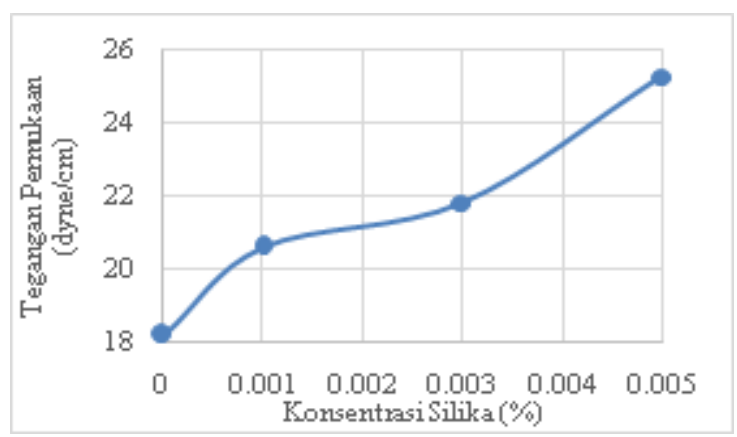

Gambar 4. Pengaruh variasi konsentrasi silika terhadap tegangan permukaan

Gambar 4 menunjukkan semakin tinggi konsentrasi silika yang ditambahkan ke dalam larutan surfaktan, maka akan semakin meningkatkan nilai tegangan permukaannya. Penjelasan untuk hal ini sama dengan penjelasan meningkatnya tegangan permukaan karena peningkatan waktu pematangan. Meningkatnya konsentrasi silika nanopartikel berarti meningkatkan luas permukaan tempat terjadinya adsorbsi fisik molekul surfaktan oleh silika sehingga semakin tinggi konsentrasi silika nanopartikel yang ditambahkan ke dalam surfaktan akan membuat semakin banyak molekul surfaktan yang teradsorbsi oleh silika dan menyebabkan terjadinya peningkatan tegangan permukaan [9].

Dari kurva pengaruh variasi konsentrasi silika terhadap waktu paruh (Gambar 5) terlihat bahwa penambahan silika nanopartikel dapat meningkatkan waktu paruh busa yang dihasilkan. Waktu paruh paling tinggi dihasilkan oleh penambahan konsentrasi silika nanopartikel sebanyak $0,001 \%$. Hal ini terjadi karena adanya silika nanopartikel di dalam lamella gelembung busa dapat menghambat terjadinya proses penuaan busa, yakni drainase serta dikuti oleh peristiwa coarsening dan coalescene [3][7].

Silika nanopartikel memiliki kemampuan untuk membentuk lapisan film padat dengan teradsorbsi pada antar muka gas/liquid yang mengakibatkan terjadinya perbedaan viskositas di sekitar lapisan film busa, yang mana hal ini dapat meminimalisir terjadinya drainase dan penuaan busa sebagai penyebab ketidakstabilan busa dalam 
jangka waktu yang lama [9]. Peningkatan stabilitas busa dapat terlihat dengan meningkatnya waktu paruh busa, pada kondisi optimal silika nanopartikel yang teradsorbsi akan membentuk lapisan monolayer atau multilayer dan meningkatkan ketebalan lapisan film busa, serta busa yang dihasilkan memiliki diameter yang cenderung lebih kecil jika dibandingkan busa yang dihasilkan hanya dengan menggunakan surfaktan saja, namun pada konsentrasi silika nanopartikel yang terlalu tinggi dapat menyebabkan proses adsorbsi pada lapisan film busa menjadi tidak berjalan dengan baik, akibatnya busa akan lebih mudah pecah dan tidak stabil dalam jangka waktu tertentu [3][4].

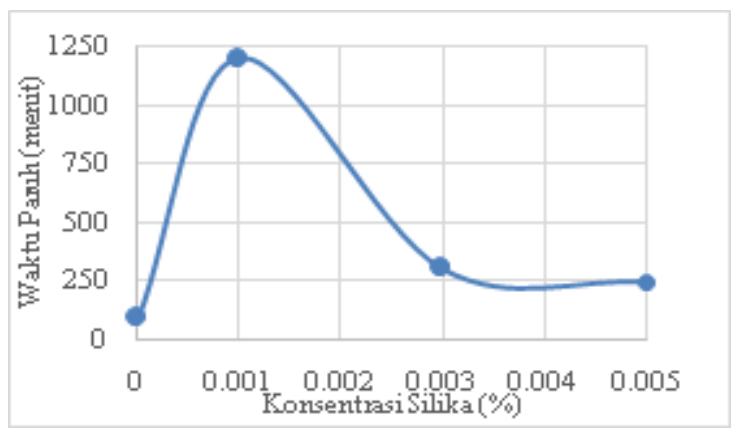

Gambar 5. Pengaruh variasi konsentrasi silika terhadap waktu paruh busa

Kestabilan busa diamati seiring perubahan waktu yang ditunjukkan oleh Gambar 6 jelas terlihat bahwa busa yang pada awalnya berukuran kecil dan sangat rapat seiring dengan waktu ukurannya membesar dan kerapatannya berkurang. Ketinggian busa tidak banyak berkurang, tetapi ukuran dan kerapatannya terus berubah. Mekanisme yang terjadi pada busa siring dengan perubahan waktu menunjukkan terjadinya peristiwa penuaan pada busa, yakni drainase, coarsening, dan coalescene yang terjadi secara simultan, sehingga busa cenderung tidak stabil dalam kondisi waktu tertentu.

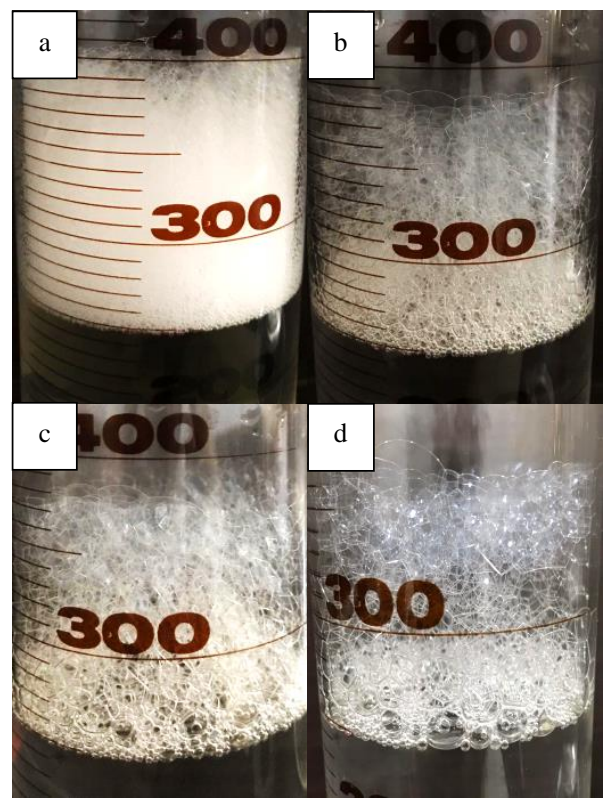

Gambar 6. Pengamatan fisik busa dengan konsentrasi silika $0,003 \%$ pada menit ke-(a) 60 , (b) 180 , (c) 240 , (d) 300
Pengamatan terhadap kestabilan busa juga ditunjukkan Gambar 7 dalam profil penurunan ketinggian busa, tampak dalam gambar tersebut bahwa variasi konsentrasi silika yang berbeda menunjukkan pola penurunan ketingian busa yang berbeda. Berdasarkan pola yang terbentuk kestabilan busa terbagi kedalam 3 fase, fase pertama pada waktu awal busa cenderung tidak stabil ditunjukkan dengan penurunan ketinggian busa yang relatif curam, memasuki fase kedua pada waktu pertengahan memiliki pola yang relatif stabil dengan penurunan ketinggian busa yang tidak terlalu signifikan, hal ini menunjukkan pada fase kedua ketinggian busa yang relatif stabil terjadi karena ukuran busa menjadi lebih besar dan seolah memiliki ketinggian yang sama, meskipun ada sebagian busa yang pecah, namun memasuki fase ketiga pada waktu akhir busa kembali pada kondisi yang tidak stabil, dengan pola penurunan ketinggian busa yang lebih curam daripada fase pertama, tidak stabilnya busa pada waktu akhir terjadi karena ukuran busa yang membesar menyebabkan lapisan film pada busa tidak dapat menahan tekanan udara di dalam busa, sehingga busa menjadi tidak stabil dan pecah.

Pembusaan paling tinggi diperoleh dari penambahan silika nanopartikel sebanyak $0,005 \%$, tetapi busanya cenderung tidak stabil hingga dicapai waktu paruhnya selama 240 menit, surfaktan dengan penambahan silika sebesar $0,001 \%$ sebagai stabilizer memiliki pola yang paling stabil dengan waktu paruh yang paling lama. Sedangkan pada penambahan silika nanopartikel $0,001 \%$ tampak pembusaan yang cukup tinggi meskipun bukan yang tertinggi, namun memiliki waktu paruh yang lebih lama, yakni mencapai 1170 menit.

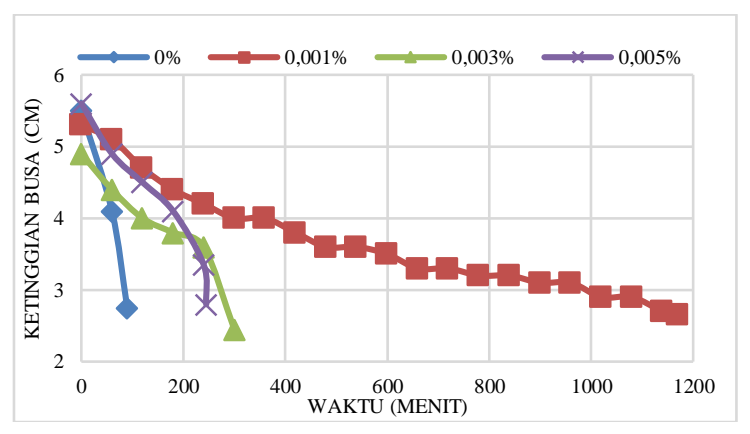

Gambar 7. Profil penurunan ketinggian busa terhadap

waktu dengan variasi konsentrasi silika

Dengan demikian silika nanopartikel yang disintesis dari $\mathrm{Na}_{2} \mathrm{SiO}_{3}$ dapat digunakan sebagai stabilizer busa. Penambahan silika nanopartikel telah berhasil meningkatkan stabilitas busa, penggunaan surfaktan saja menunjukkan waktu paruh selama 90 menit, sedangkan pada surfaktan dengan penambahan silika nanopartikel $0,001 \%$ dan waktu pematangan selama 6 jam dapat mencapai waktu paruh yang jauh lebih lama, mencapai 1170 menit atau 13 kali lipatnya.

\section{KESIMPULAN}

Pengaplikasian nanofluida berbasis $\mathrm{SiO}_{2}$ yang disintesa dari $\mathrm{Na}_{2} \mathrm{SiO}_{3}$ pada surfaktan telah berhasil meningkatkan stabilitas busa yang dihasilkan. Peningkatan waktu pematangan dan konsentrasi silika menunjukkan hubungan 
terhadap peningkatan nilai tegangan permukaan dan waktu paruh busa. Diperoleh peningkatan waktu paruh tertinggi dari semula 90 menit pada sampel tanpa penambahan silika nanopartikel menjadi 1170 menit atau 13 kali pada penambahan silika nanopartikel $0,001 \%$ dengan waktu pematangan selama 6 jam.

\section{UCAPAN TERIMA KASIH}

Penelitian ini merupakan bagian dari penelitian yang didanai oleh Kementrian Riset Teknologi dan Pendidikan Tinggi melalui Program Penelitian Disertasi Doktor tahun 2019-2020. Karenanya diucapkan terima kasih.

\section{DAFTAR PUSTAKA}

[1] Z. Liu and L. E. Zerpa, "Preliminary Study of Liquid Loading Problems for Gas Hydrate Wells and," 2016.

[2] C. Sarica and M. Kelkar, "Gas Well Pressure Drop Prediction under Foam Flow Conditions, ” 2015.

[3] A. L. Fameau and A. Salonen, "Effect of particles and aggregated structures on the foam stability and aging," Comptes Rendus Phys., vol. 15, no. 8-9, pp. 748-760, 2014.

[4] J. Li et al., "Prospect of Production Optimization Challenges of Gas Wells with Liquid Loading Problem Using New Surfactant and Nanotechnology," 2015.

[5] J. WU et al., "A nano-particle foam unloading agent applied in unloading liquid of deep gas well," Pet. Explor. Dev., vol. 43, no. 4, pp. 695-700, 2016.

[6] L. Qomariyah, F. N. Sasmita, H. R. Novaldi, W. Widiyastuti, and S. Winardi, "Preparation of Stable Colloidal Silica with Controlled Size Nano Spheres from Sodium Silicate Solution," IOP Conf. Ser. Mater. Sci. Eng., vol. 395, no. 1, 2018.

[7] B. Vishal and P. Ghosh, "The effect of silica nanoparticles on the stability of aqueous foams," $J$. Dispers. Sci. Technol., vol. 0, no. 0, pp. 1-13, 2018.

[8] H. Mawarani, L.J.; Ajiz, H.A.; Widiyastuti, Setyawan, "168-Manuscript-1301-1-18-20191118," in Effect of Nanosilica on Foam Stabilities of Sodium Lauryl Sulfate and Polysorbate Mixture.

[9] S. Yusuf, M. Manan, and M. Z. Jaafar, "Aqueous Foams Stabilized by Hydrophilic Silica Nanoparticles via In-Situ Physisorption of Nonionic TX100 Surfactant," Iran. J. Energy Environ., vol. 4, no. 1, pp. 8-16, 2013.

[10] J. Yang, V. Jovancicevic, and S. Ramachandran, "Foam for gas well deliquification," Colloids Surfaces A Physicochem. Eng. Asp., vol. 309, no. 1-3, pp. 177181, 2007. 